\title{
Karakteristik Lokal Pengrajin Gerabah Terhadap Kualitas Produk Gerabah Desa Maregam Kota Tidore Kepulauan
}

\author{
Kusrini $^{1}$ \\ ${ }^{1}$ Program Studi Pendidikan Geografi FKIP Unkhair \\ Email : Kusrini.kds@gmail.com
}

(Received: Agustus 2019; Reviewed: Agustus 2019; Accepted: September 2019; Published: September 2019)

\begin{abstract}
The study was carried out in Maregam Village, South Tidore District, Tidore Islands City. This study aims to determine the local characteristics of pottery craftsmen on the quality of the products produced. The number of pottery craftsmen in the village of Maregam is 66 households. Pottery is only done by women (wives) who have inherited it from generation to generation and has become a tradition in the community in the village of Maregam. Making pottery is one of the main livelihoods for residents of Maregam Village besides fishermen and farmers. This research is descriptive using secondary data and field survey data with a questionnaire instrument and direct interviews with key informants at the research location with triangulation data analysis.
\end{abstract}

Keywords: Maregam Village; Pottery Crafts; Local Characteristics

\begin{abstract}
ABSTRAK
Penelitian dilaksanakan di Desa Maregam, Kecamatan Tidore Selatan Kota Tidore Kepulauan. Penelitian ini bertujuan untuk mengetahui karakteristik lokal pengrajin gerabah terhadap kualitas produk yang dihasilkan. Jumlah pengrajin gerabah di desa Maregam terdapat 66 KK. Kerajinan gerabah hanya dikerjakan oleh kaum perempuan (istri) yang telah mewarisinya secara turun temurun serta sudah menjadi tradisi dalam masyarakat di Desa Maregam. Pembuatan gerabah merupakan salah satu mata pencaharian utama untuk penduduk Desa Maregam selain nelayan dan petani. Penelitian ini bersifat deskriptif menggunakan data sekunder dan data survey lapangan dengan alat instrument kuesioner dan wawancara langsung terhadap informan kunci di lokasi penelitian dengan analisis data triangulasi.
\end{abstract}

Kata Kunci: Desa Maregam; Kerajinan Gerabah; Karakteristik Lokal

\section{PENDAHULUAN}

Sumberdaya alam kepulauan Indonesia yang berlimpah diantaranya tanah yang subur, laut yang kaya potensi ikan, sumberdaya mineral tanah dan batuan merupakan potensi yang besar dimiliki bangsa Indonesia. Kekayaan sumberdaya alam dapat diolah dan dimanfaatkan untuk meningkatkan kesejahteraan masyarakat. 
Desa Maregam salah satu wilayah administrasi yang terletak di Pulau Mare Kota Tidore Kepulauan yang memiliki potensi sumberdays alam berupa kekayaan tanah liat yang dapat dimanfaatkan sebagai bahan baku pembuatan gerabah. Disamping itu, kemampuan dan keterampilan yang dimiliki merupakan warisan secara turun temurun masyarakatnya sebagai pengrajin gerabah walaupun masih menggunakan teknologi sederhana. Salah satu sisi keunikan pembuatan gerabah adalah kaum wanita dijadikan sebagai titk sentral dan untuk kepercayaan tersebut masih dipegang teguh oleh masyarakat Desa Maregam sampai saat ini.

Usaha pembuatan gerabah juga masih dilakukan di masing-masing rumah warga sekaligus dijadikan ikon kerajinan rumah tangga masyarakatnya. Sebagai sentra kerajinan gerabah di Propinsi Maluku Utara, masyarakat Maregam berpeluang untuk dikembangkan menjadi usaha kerajinan kreatif yang lebih modern, sehingga akan berpengaruh pada tingkat kesejahteraan dan kualitas produk gerabah di desa Maregam. Menurut Rakib (2017), pengembangan ekonomi kreatif berbasis kearifan lokal merupakan konsep mengembangkan potensi alam, budaya, dan tradisi yang dimiliki oleh masyarakat setempat.

Adapun tujuan penelitian ini adalah untuk mengetahui keunikan kerajinan gerabah terhadap aspek keluarga pengrajin, dan kualitas produk dan lingkungan geografisnya. Selain itu penelitian ini juga digunakan sebagai sarana informatif masyarakat Maluku Utara terhadap keunggulan produk gerabah dari Desa Maregam.

\section{METODE}

Lokasi Penelitian ini terletak desa Maregam dengan kondisi geografis $127^{\circ} 23^{\prime}$ $0^{\prime \prime}-127^{\circ} 25^{\prime} 0^{\prime \prime}$ Bujur Timur dan $0^{\circ} 35^{\prime}-0^{\circ}$ 34' Lintang Selatan dan luas wilayah $650 \mathrm{Ha}$. Populasinya masyarakat Desa Maregam yang tersebar pada $2 \mathrm{RW}$ dan 4 RT dengan jumlah penduduk 428 Jiwa. Pemilihan lokasi penelitian ini didasari karena Desa Maregam di Pulau Mare Kota Tidore Kepulauan adalah pulau yang masyarakatnya memiliki keterampilan tertentu khususnya kaum perempuan dalam mengolah tanah liat menjadi kerajinan gerabah yang satu satunya di lingkungan wilayah kepulauan Maluku Utara.

Penelitian ini merupakan penelitian deskriptif dengan data yang digunakan adalah data sekunder dan data survei lapangan dengan alat instrumen kuesioner dan wawancara langsung terhadap informan kunci di lokasi penelitian. Responden yang menjadi sumber data penelitian ini adalah masyarakat yang bermukim di Pulau Mare yang memiliki aktivitas sebagai pengrajin gerabah. Adapun teknik pengumpulan data yang digunakan untuk mengecek keabsahan data wawancara dari responden menggunakan analisis data triangulasi. Triangulasi adalah suatu cara mendapatkan data yang benar-benar absah yang menggunakan pendekatan metode ganda, dengan cara memanfaatkan suatu yang lain di luar data itu sendiri.

\section{HASIL DAN PEMBAHASAN}

Sebagai sentra kerajinan gerabah di Provinsi Maluku Utara, penduduk Desa Maregam memiliki keterampilan unggulan dalam pembuatan gerabah. Gerabah-gerabah yang dihasilkan akan dipasarkan di seluruh Maluku Utara, bahkan hingga ke luar provinsi Maluku Utara. Semakin jauh jangkauan wilayah pemasaran, menunjukkan semakin tinggi harga gerabah tersebut. Berbagai gerabah-gerabah yang di hasilkan oleh masyarakat Desa Maregam adalah ngurangura (penutup wadah) tempat dupa dan belanga dengan berbagai ukuran dan bentuk.

Seiring perkembangan zaman, ragam bentuk gerabah mencerminkan tingkat kebutuhan semakin bervariatif dan memerlukan terobosan baru pada alat-alat pembuatan gerabah untuk menghasilkan produk gerabah dengan berbagai ragam desain motif. Kenyataan di lapangan, menunjukkan faktor keterbatasan modal, hingga saat ini produktivitas gerabah di desa Maregam masih mengandalkan alat-alat tradisional, seperti gula-gula, mafu, nyou, kosa, jako, bilalu dan lain-lain. Walaupun dalam proses pembuatan gerabah tersebut membutuhkan waktu yang 
lama, tetapi para pengrajin tetap berupaya keras menghasilkan gerabah untuk dipasarkan ke pulau-pulau sekitarnya.

\section{a. Karakteristrik lokal dalam lingkup keluarga pengrajin gerabah Desa Maregam}

Ciri yang khas pengrajin gerabah di Desa Maregam yaitu keharusan pengrajin gerabah adalah kaum perempuan karena terdapat kepercayaan masyarakat yang berlangsung hingga kini yakni adanya kepercayaan pada hal buruk bakal terjadi apabila kaum pria turut campur dalam pembuatan gerabah untuk keperluan alat-alat dapur tersebut. Aturan adat turun temurun sampai sekarang masih teguh dilestarikan oleh masyarakat Desa Maregam. Mengamati hasil produk kerajinan gerabah di Desa Maregam sebagian besar masih bertumpu pada tujuan pemenuhan alat-alat dapur, pertanian, dan ritual keagamaan.

Dalam sebaran jumlah penduduk berdasarkan data monografi Desa Maregam yang disajikan dalam tabel 1 memberi gambaran jumlah masyarakat yang termasuk usia produktif adalah $73 \%$ dan jumlah persentase tersebut merupakan cerminan potensi sumberdaya yang dimiliki cukup tinggi.

Tabel 1. Sebaran penduduk berdasarkan tingkat usia produktivitas kerja Desa Maregam

\begin{tabular}{|l|l|l|l|l|}
\hline Jenis Kelamin & $\begin{array}{l}\text { Usia Belum } \\
\text { Produktif (jiwa) }\end{array}$ & $\begin{array}{l}\text { Usia Produktif } \\
\text { (Jiwa) }\end{array}$ & $\begin{array}{l}\text { Usia Tidak } \\
\text { Produktif (Jiwa) }\end{array}$ & Total \\
\hline & $0-<15$ & $15-64$ & $>64$ & \\
\hline Laki-Laki & 56 & 161 & 5 & 222 \\
\hline Perempuan & 48 & 150 & 8 & 206 \\
\hline Persentase (\%) & $\mathbf{2 4}$ & $\mathbf{7 3}$ & $\mathbf{3}$ & \\
\hline
\end{tabular}

Sumber: Monografi Desa Maregam 2018.

Potensi sumberdaya Desa Maregam yang besar tersebut, karakteristik angkatan kerja produktif dan mata pencahariannya sebagai pengrajin gerabah yaitu jumlahnya 66 Kepala Keluarga (KK) dan selengkapnya dapat dilihat pada gambar 1 berikut :

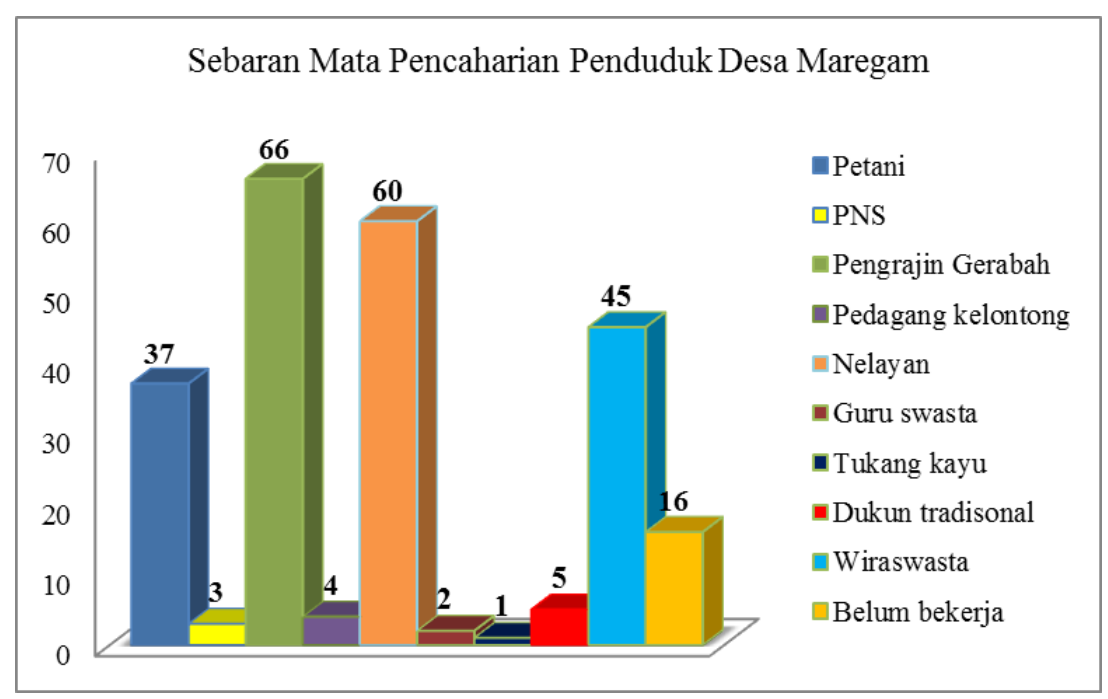

Gambar 1. Sebaran mata pencaharian penduduk Desa Maregam (Sumber: Monografi Desa Maregam 2018) 
Berdasarkan jumlah kepala keluarga tersebut, usaha kerajinan gerabah adalah merupakan mata pencaharian utama terhadap keluarga di Desa Maregam. Dalam hal kedudukan usaha kerajinan gerabah dalam mendukung pendapatan keluarga, keberadaan usaha pembuatan gerabah mampu memberikan sumbangsih besar dalam penghasilan keluarganya. Penghasilan keluarga mampu mendorong kesejahteraan keluarga sehingga memenuhi kualitas hidup mereka. Usaha kerajinan gerabah memiliki potensi untuk meningkatkan kesejahteraan kehidupan keluarga. Sebagaimana halnya, Hoelman dan Fanggaiedae (2016),

mengemukakan kesejahteraan sosial mencangkup dua konsepsi. Pertama, kesejahteraan sosial mencakup keseluruhan kualitas hidup manusia. Kedua, kesejatraan sosial dalam artian yang terbatas, bahkan cenderung sempit dan dalam konsepsi yang kedua kesejatraan sosial identik dengan pelengkap (complementary).

Berdasarkan analisis data dari ke-66 KK yang menjadi responden menggambarkan bahwa $88 \%$ pembuatan kerajinan gerabah merupakan pekerjaan utama untuk keluarga masyarakat Desa Maregam (terlihat pada gambar 2).

Gambar 2. Status kerja pengrajin gerabah Desa Maregam (Sumber: olahan data 2019)

Apabila dikorelasikan dengan data kategori usia responden yang memilih pengrajin sebagai pekerjaan utama, seperti dalam tabel 2, maka usia dewasa mapan atau umur pengrajin antara 40-56 tahun memiliki persentase yang dominan yakni 53\%. Persentase tinggi tersebut dapat menggambarkan keadaan pengrajin gerabah yang dimaksudkan oleh Daldjoeni bersesuaian dengan usia dewasa lanjut dari pengrajin gerabah Desa Maregam.

Selain itu, persentase usia dewasa atau pengrajin yang berumur kurang dari 40 tahun cenderung memilih pekerjaan membuat gerabah tidak menjadi satu satunya pekerjaan utama mereka melainkan juga aktif dengan

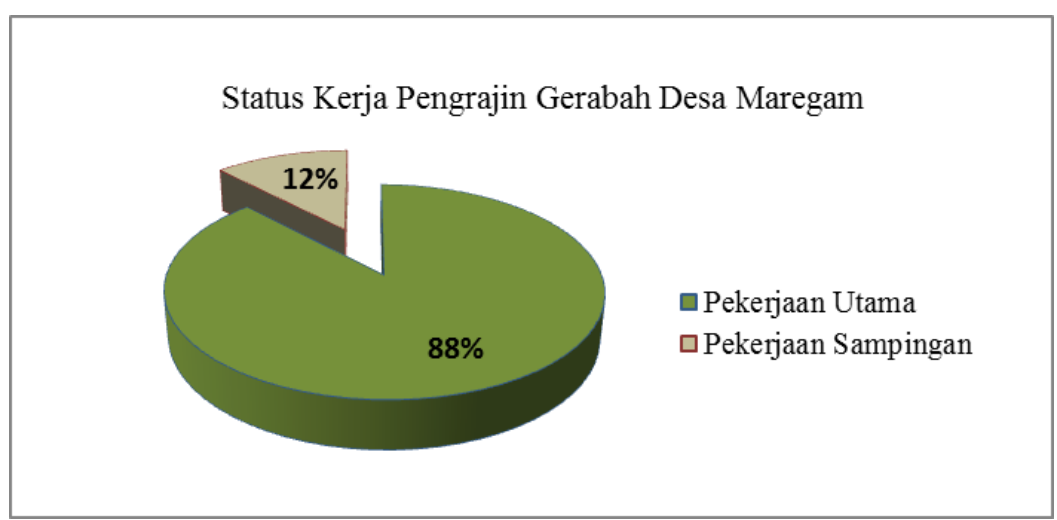

hanya berfokus pada pekerjaan membuat pekerjaan lainnya. Karakteristik tingkatan gerabah dan sekaligus menjadi sumber kategori usia dewasa, dewasa mapan, atau penghasilan keluarga yang utama. Hal yang dewasa lanjut terhadap keluarga pengrajin sama dikemukakan Daldjoeni (1977), umur gerabah dapat memberikan penjelasan tentang antara 55-64 tahun sudah dikategorikan kondisi atau motivasi kerja pengrajin sehingga sebagai usia tidak produktif penuh atau mendorong mereka untuk giat dan ulet dalam mejelang tidak produktif lagi. Kategori umur menekuni kerajinan rumah tangga tersebut.

Tabel 2. Kategori usia penduduk dengan pekerjaan utama pengrajin gerabah

\begin{tabular}{l|l|l|l} 
Kategori Umur (Th) & Frekuensi (KK) & Persentase (\%) & Keterangan
\end{tabular}




\begin{tabular}{|c|l|l|l|}
\hline$<40$ & 18 & 27 & usia dewasa \\
\hline $40-56$ & 35 & 53 & usia dewasa mapan \\
\hline$>56$ & 13 & 20 & usia dewasa lanjut \\
\hline Jumlah & $\mathbf{6 6}$ & & \\
\hline
\end{tabular}

Sumber: olahan data 2019

Berbeda dengan tingkat pendidikan yang dimiliki pengrajin hanya sampai pada tingkat Sekolah Dasar menggambarkan kapasitas pengrajin berpendidikan SD dengan jumlah 73\% seperti terlihat pada table 3 . Kapasitas yang tinggi tersebut, menunjukkan tingkat pendidikan kurang berkorelasi terhadap usaha kerajinan gerabah di Desa Maregam. Untuk tingkat pendidikan SMP dan
SMA dimiliki oleh pengrajin gerabah juga menggambarkan bahwa pekerjaan sebagai pengrajin gerabah bukan merupakan satusatunya pekerjaan yang sedang digelutinya. Sebagian besar dari pengrajin yang berpendidikan SMP dan SMA memiliki usia kurang dari 40 tahun sekaligus menjadi tulang punggung

keluarganya.

Tabel 3. Tingkat pendidikan dengan pekerjaan pengrajin gerabah

\begin{tabular}{|c|c|c|}
\hline $\begin{array}{c}\text { Tingkat } \\
\text { Pendidikan }\end{array}$ & Frekuensi & Persentase \\
\hline SD & 48 & 73 \\
\hline SMP & 8 & 12 \\
\hline SMA & 10 & 15 \\
\hline Jumlah & $\mathbf{6 6}$ & \\
\hline
\end{tabular}

Sumber: olahan data 2019

Adapun karakteristik tertentu dan berlaku menyeluruh terhadap pengrajin gerabah di Desa Maregam adalah membuat gerabah merupakan bagian dari semagat spiritual kehidupannya yang sudah turun temurun diwariskan oleh pendahulunya dan tidak terlalu banyak terpengaruh oleh ukuran keuntungan yang diperoleh bagi keluarganya. Karakteristik lokal tersebut merupakan aspek utama untuk dikembangkan sebagai industri kreatif. Sehubungan tentang industri kreatif, Nurchayati dan Ratnawati (2016) memandang sebagai industri yang tidak mementingkan skala produksi dalam jumlah besar, tetapi bertumpu pada kualitas sumber daya manusia atau industri yang tercipta karena potensi keunikan yang dimilikinya. Faktor adat atau tradisi yang kental masih dipegang teguh dan merupakan suatu wasiat dari $M o$ 'Re, Leluhur mereka dan pembuat gerabah kali pertama di Pulau Mare dengan mewasiatkan "ada lima motif gerabah yang hanya boleh dibuat pada waktu tertentu dan hanya kaum perempuan tertentu yang diperbolehkan untuk membuatnya".

Pelanggaran terhadap wasiat tersebut dapat mendatangkan bala musibah tidak hanya keluarganya tetapi juga dalam masyarakat desa Pulau Mare. Semangat spiritual tersebut secara langsung berdampak terhadap penerimaan secara tulus dan pola hidup sederhana. Semangat tersebut juga berpengaruh terhadap modernisasi peralatanperalatan pembuat gerabahnya terkesan lambat dan masih mengandalkan cara tradisional serta belum menjadi perhatian khusus untuk pengembangan produk kerajinan gerabahnya. Suatu daya tarik dan keterampilan tertentu dimiliki oleh perempuan pengrajin gerabah meskipun dikerjakan tidak menggunakan alat atau teknologi modern, tetapi pada akhirnya kreativitas seni gerabah 
tetap dijaga dan ditekuni dengan berbagai ragam ukuran produk yang dihasilkan tetap seragam.

\section{b. Karakteristik Produk Gerabah Desa Maregam dan lingkungan geografisnya}

Secara historis keberadaan kerajinan gerabah di Pulau Mare tidak lepas dari kebijakan Sultan Nuku sebagai Sultan tersohor dalam Kesultanan Tidore tahun 1797. Kebijakan yang dikeluarkan yakni setiap kampong atau daerah dalam wilayah kesultanannya terdapat produk unggulan yang mencirikan daerahnya dengan menyesuaikan potensi alam masing-masing daerah untuk

Gambar 3. Ragam produk gerabah Desa Maregam (Sumber: dokumentasi lapangan 2019)

Beberapa fungsi peralatan gerabah selalu berkaitan dengan kebutuhan hidup masyarakat Maluku Utara. Produk gerabah

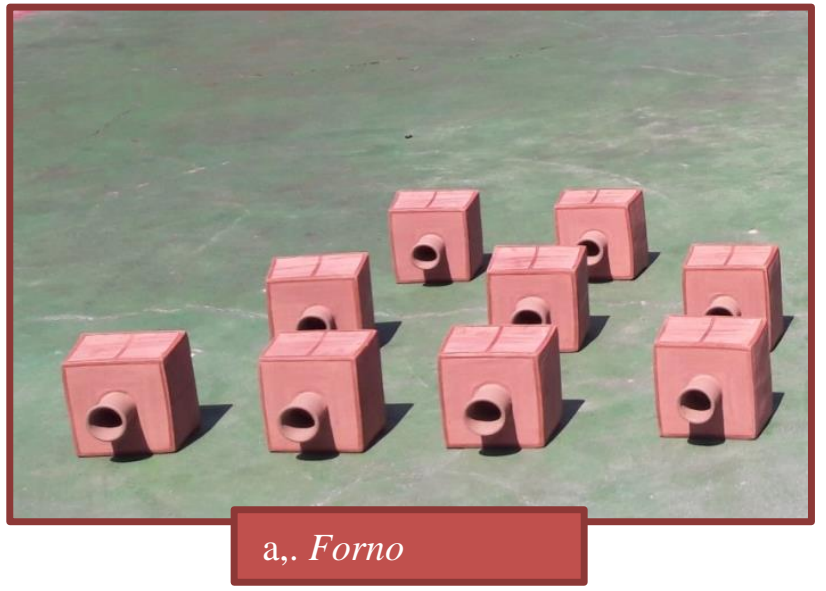

Forno misalnya, merupakan alat percetakan sagu. Sagu merupakan makanan pokok masyarakat Maluku Utara sehingga gerabah tersebut menjadi bagian ketahanan pangan di wilayah Maluku Utara, boso-mare (belanga) dan bura-bura (bahasa Tidore) atau ngurangura (bahasa Ternate) merupakan alat memasak kuliner khas Maluku Utara seperti kue apam Ternate, lapis Tidore dan lapis Sanana, Begitu pun sendok gerabah, yang digunakan untuk membakar arang, dan hito (tempat kemenyan) untuk wadah arang yang sudah dibakar bersama kemenyan. Ke-dua

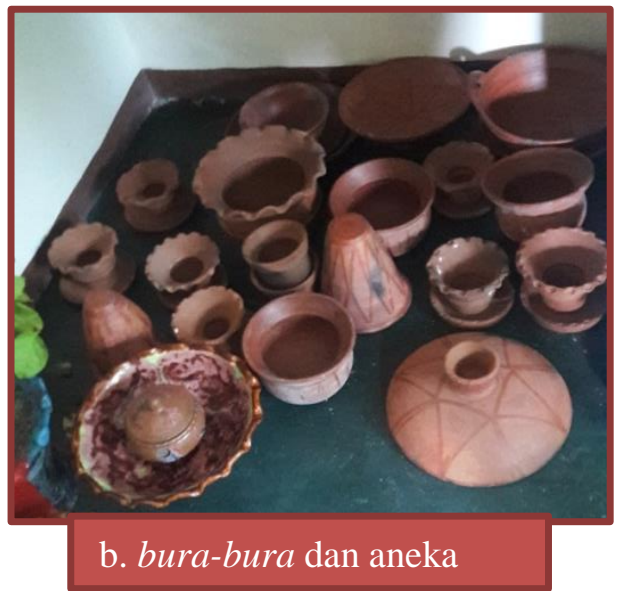

dipertukarkan dengan kebutuhan pangan dari kampong lainnya.

Dampak kebijakan tersebut, Pulau Mare menjadi satu satunya daerah atau pulau yang dapat ditemui pengrajin gerabah di wilayah kepulauan Maluku Utara. Gerabahgerabah hasil produk Desa Maregam menjadi kebutuhan utama dalam kehidupan, tidak hanya sebagai pelengkap dalam kebutuhan peralatan dapur juga diperlukan oleh petani sebagai kelengkapan wajib dalam fase awal bercocok tanam serta dalam pelaksanaan ritual-ritual keagamaan (dapat dilihat pada gambar 3).

perkakas sendok gerabah dan hito difungsikan dalam ritual tahlilan, mendoakan orang maupun hajatan untuk orang meninggal.

Fungsi-fungsi gerabah tersebut sebagaimana dikemukakan Addien (2010), gerabah merupakan perkakas yang terbuat dari tanah liat atau lempung yang dibentuk kemudian dibakar untuk dijadikan alat-alat yang berguna dalam membantu kehidupan.

Kualitas pasokan produk gerabah dari Pulau Mare memiliki ketergantungan pada sumberdaya alam di desa Maregam sendiri. Ketersedian tanah liat yang khas dan hanya dijumpai di Pulau Mare tersebut mempengaruhi proses pembuatan hingga kuantitas produk gerabah. Sehubungan faktor 
geografisnya, untuk menghasilkan satu buah gerabah ditentukan pada sumber daya pendukung yang hanya terdapat di Pulau Halmahera (Oba) yaitu bahan pasir hitam dan tanah merah supaya memperoleh komposisi tanah liat yang bersifat plastis. Menurut Saleh dkk., 2019 kualitas bahan baku tanah liat yang kurang plastis dapat mempengaruhi kualitas produk gerabah, Ketergantungan bahan baku material yang terpisah pulau secara geografis, dapat menciptakan suatu interaksi spasial sebagaimana halnya masyarakat di Pulau Halmahera sangat bergantung pada hasil gerabah dari Pulau Mare untuk digunakan sebagai kelengkapan dalam melakukan cocok tanam, dan sebaliknya material pendukung pasir hitam dan tanah merah merupakan komponen perekat untuk pembuatan gerabah Pulau Mare.

Salah satu tantangan kedepan untuk pengembangan kerajinan gerabah di Pulau Mare adalah aksesibilitas dan kecukupan bahan baku pendudung terdapat di Oba Pulau Halmahera.. Tantangan tersebut merupakan faktor pembatas geografis seperti laut beserta sarana transportasinya. Untuk faktor kelancaran transportasi penghubung kedua pulau tersebut atau pulau sekitarnya belum banyak terjangkau dari Desa Maregam Pulau Mare.

\section{SIMPULAN DAN SARAN}

Corak Karakteristrik lokal pengrajin gerabah Desa Maregam adalah aturan adat istiadat Desa Maregam yang boleh membuat kerajinan gerabah hanya perempuan sedangkan kaum laki-laki hanya boleh membantu dalam penyiapan bahan baku. Keberadaan kepercayaan setempat yang masih teguh dilestarikan sampai sekarang, jika yang membuat gerabah kaum laki-laki akan ada hal buruk yang terjadi di Desa Maregam. Produktivitas kerajinan gerabah Desa Maregam masih menggunakan peralatan tradisional dan keterampilan yang diturunkan oleh orangtuanya. Produk yang dihasilkan diantaranya; forno adalah alat yang digunakan membuat sagu, Ngura-ngura (penutup belanga), boso mare (belanga), hito (tempat kemenyan) dan cobek. Bahan baku kerajinan gerabah di desa Maregam selain berasal dari Desa Maregam juga didatangkan dari Oba Pulau Halmahera.

\section{DAFTAR RUJUKAN}

Addien. 2010. Praktik Pembuatan Tanah Liat. Tran Mandiri Abadi. Jakarta.

Bintarto. 1986. Buku Penuntun Geografi Sosial. U. P. Sping: Yogyakarta.

Daldjoni.1977. Pusparagam Aspirasi Manusia. Alumni Bandung

Hoelman, B. dan Fanggaiedae, V., 2016.

Tranformasi Kesejahteraan (Pemenuhan Hak Ekonomi dan Kesehatan Semesta). Jakarta: LP3ES.

Monografi Desa Maregam 2018

Nurchayati dan Ratnawati, A.T. 2016. Strategi Pengembangan Industri Kreatif Sebagai Penggerak Destinasi Pariwisata Di Kabupaten Semarang. Prosiding Seminar Nasional Multidisiplin Ilmu \& Call For Papers UNISBANK Semarang.

Rakib. M. 2017. Strategi Pengembangan Ekonomi Kreatif Berbasis Kearifan Lokal Sebagai Penunjang Daya Tarik Wisata. Jurnal Kepariwisataan. Vol. 1 No.. 2. Hal 54-69.

Saleh.J, Irfan dan Arifin I., 2019. Peningkatan Kualitas Gerabah Melalui Pengolahan Dan Penyaringan Bahan Di Sandi Kecamatan Pattallassang Kabupaten Takalar. Jurnal Imajinasi Volume 3. 2629 ,

\section{Editor In Chief \\ Rosmini Maru \\ rosminimaru@unm.ac.id}

\section{Publisher}

Geography Education, Postgraduate Program, Universitas Negeri Makassar Jl. Bonto Langkasa Gunungsari Baru Makassar, 90222 Kampus PPs UNM Makassar Gedung AB ruang 01 , Indonesia Email : ugj@unm.ac.id

Info Berlangganan Jurnal 085299874629 / Ihsan 